\title{
The Chthonic Realm of Our Psyche: Mythic and Moral Aspects of Dracula's Nature
}

Myths reflect the collective experience of mankind. Certain things recur in world myths. Carl Gustav Jung, Swiss psychologist, psychiatrist and analyst noticed that his patients' dreams contained a lot of similar motives without being acquainted with one another. He observed that these motives in dreams are akin to motives appearing in myths, tales and legends. These archaic pictures or symbols which are universally recognized, he entitled archetypes. The distant locations of vampiric entities prove that vampirism is also a universal phenomenon. In the following article I intend to explore the essential inherent mythic characteristics of Stoker's Dracula, focusing on possible conceptions of morality.

\section{Dracula as a mythic deity}

Vampires reveal a number of mythic features which can be found in several deities of world mythology. They are Creators, they have the power to give and take away lives, they are preserver and destroyer. Dracula shows similarities with many creation myths. Vampires do not need a woman to give birth that is why they are divine creatures. In this sense, they are father and mother at the same time. Since they are also lovers of the victim, a very strange incestuous relationship can be disclosed. The first gods were all incestuous: having no other partner to mate with, they often had sexual relationship with their own brother, sister, mother or father.

Vampires clearly possess godlike features. From Stoker's working notes it is known that the writer had three possible titles in mind when writing Dracula, namely Count Dracula, The Un-Dead and The Dead UnDead. These titles allude to one of the key features of the vampires, to immortality. Athanasia is an ontological boundary that separates humans from deities. Dracula's figure as a deity 
is the most striking in his relation with Renfield. Renfield's devoted exclamation that "I am here to Your bidding, Master. I am Your slave, and You will reward me, for I shall be faithful. I have worshipped You long and after off" (Stoker 1994: 126) clearly manifests that he worships Dracula. Once an attendant even remarks that Renfield behaves at times as if a "sudden form of religious mania" (124) has seized him. Not only Renfield sees Dracula as a God, Dracula makes himself be seen as a God, he is conscious of his power: "All these lives will I give you, ay, and many more and greater, through countless ages, if you will fall down and worship me!" (333) Renfield wants to benefit from the relationship with the count; he is eager to have immortality. He is obsessed with bloodlust and eternal life.

"But those who eat my flesh and drink my blood have eternal life, and I will raise them at the last day" (Holy Bible, John 6: 53-57) promises Christ the end of death and the beginning of eternal life to believers. The idea that the soul is eternal makes us humans immortal spiritual beings. The immortality myth is important for people, it gives hope that there is life after death and that we have a lot of time still. This delusion boils down to the effort to overcome our fear of death, and as Freud notes, to "maintain moral order among the living" (Freud 2001: 945). The creation of immortal supernatural entities can be seen as a power-wish, a metaphysical impossibility to conquer death, but also entails another explanation with a moral lesson. Beyond our own relation to death, we have to cope with the loss of our beloved ones. We do not know what happens after physical death, but we certainly know what it is like to lose someone close to us. The return of the dead in evil forms unconsciously inspires people to let the dead go and let their former attachment be broken off. Some old beliefs of the primitive races can be traced back in the relation between the living and the dead in civilized societies as Freud refers to R. Kleinpaul (The Living and the Dead in Folklore, Religion and Myth, 1898) in Totem and Taboo that

[a]ccording to him too, this relation culminates in the conviction that the dead, thirsting for blood, draw the living after them. The living did not feel themselves safe from the persecutions of the 
MUSKOVITS

dead until a body of water had been put between them. That is why it was preferred to bury the dead on islands or to bring them to the other side of a river, the expressions "here" and "beyond" originated in this way. Later moderation has restricted the malevolence of the dead to those categories where a peculiar right to feel rancor had to be admitted, such as the murdered who pursue their murderer as evil spirits, and those who, like brides, had died with their longings unsatisfied. Kleinpaul believes that originally, however, the dead were all vampires, who bore ill-will to the living, and strove to harm them and deprive them of life. It was the corpse that first furnished the conception of an evil spirit. (Freud 1918: 99)

The dead crave for blood, that is, they bear the primary qualities of a vampire. The vampires become parasites who can live only with the help of human's blood, or rather, they are parasitoid, because they finally destroy their host, leastways they deprive the soul of their $\operatorname{victim}(\mathrm{s})$ from salvation.

It is important to note that despite the glorious imagination of Christian afterlife, vampires' immortality means damnation. The vampire turns the ideal representative image of the good Christian upside down, whose body is temporary but his soul is eternal. In contrast, the undead bloodsuckers' body, physicality is what is eternal, but their soul is already lost. This immortality is paradoxical though, because they can be destroyed. Religious objects are proper weapons against them since a vampire is an anti-God, who does not provide morality principles and lacks ethical attitudes. Their form reveals to people the danger of not yielding to the Christian religious belief system, and the consequences of leading an immoral or amoral life. Religion and cultural values are intertwined in the character of the vampire.

In Stoker's Dracula Renfield realizes this illusionary aspect of immortality. First, he succumbs to the temptation of everlasting life, but then he changes his mind when he feels being burdened with souls. In order to keep up their undead existence, vampires need to drink blood, they are with blood fixation. "The blood is the life! the blood is the life!" cries Renfield in Stoker's Dracula after he cuts Dr Seward's left wrist, and licks up the vital liquid from the floor (171). 
Blood as being equal to life is a very ancient myth of mankind. It was early recognized by tribal societies that losing too much blood resulted in losing one's life, therefore they attributed the red liquid with magical properties. Drinking from the enemy's blood was a superstitious belief of conveying the power of the deceased. In vampire myth it is blood through which the materialization of the evil spirit can come through. The sanguine fluid serves as a mediator between the living and the dead, which makes it possible for the dead to animate and come back to haunt human beings. Blood is the main element in the vampire creation myth, but it is clear that sanguine drops were primary elements for creating humans in several other myths worldwide.

In the creation myth of Babylonia, the primordial mother Tiamat's son Kingu played a significant role. After Marduk cut Tiamat's body into two pieces, thus creating sky from her upper-, and earth from her lower body, he used Kingu's blood in order to create the first humans. Pre-Columbian Mesoamerica is pervaded by blood symbolism, too. The priests held down the victim, stretched him out and cut out his heart while alive with an obsidian knife. With this method they sacrificed thousands of people. Behind these barbarous acts lay the belief of their creation myth. According to legends, the god Quetzalcoatl sacrificed himself, gave his own blood in order to animate the ancestors' bones, and with him several other gods made themselves bleed for humans. In securing the cycle of nature, the Aztecs gave human blood in return. The victims of the Aztecs not only died for the gods, but were seen as deities themselves, thus recurring the auto-sacrificial bloodletting of their deities. This sacrifice for humans is apparent also in Christian myth when Jesus Christ gave his own blood and life for humans' sins ${ }^{1}$.

\footnotetext{
${ }^{1}$ Nevertheless, the loss of blood does not always have fatal consequences. In the Middle Ages in order to remove the contaminated bodily fluids from the patient's circulatory system, as a medical practise, bloodletting was used. Another medical method, blood transfusion had been used to replace blood of anaemic people, and through this auto-sacrificial act another person's life could be saved.
} 
MUSKOVITS

\section{Ethical problems of sex with the vampire}

The vampire legends' blood myth is undercurrent with eroticism. The act of blood-taking is more intimate than it seems at first sight. The first physical contact brings about a close relationship immediately, a strong mental and physical dependence between the vampire and his victim. The target of the vampiric kiss is the victim's neck. Critics often claim that bloodsucking in this way becomes a metaphor of sexual intercourse. This observation can be justified easily, examining the touching of the vampire and the victimized person. The vampire plunges his fangs (phallic symbol) into his victim's neck. A penetrating and a receiving organ play part in this act, during which bodily fluids intermingle. The fangs and the bloody scar on the neck become supplementary sexual organs. So, those human beings transformed into a vampire will become new creatures possessing active and passive organs as well. They own sexual duality. They become hermaphrodites: male on the mouth and female on their neck. ${ }^{2}$

Human sexuality carries finality in itself; death is a reality principle. Eternal life is something that human beings cannot experience. Belief in afterlife is common to a lot of religions, it helps to endure our limited earthly existence. The only way to "live on" is through offsprings, which holds out a promise of some kind of eternity, thus immortality and sexuality motifs are correlated. The pleasure principle forces the issue of generation. In Dracula it is also through sexuality how one experiences infinite state. Dracula is a liminal numen, the multi-level junction of sex and death. According to Bunson, the physical sensation of sex with a vampire is just one part

${ }^{2}$ This gender crossing in the domain of deities is not uncommon. The Egyptian primal sun god, Amenhotep is depicted as clearly androgynous. The Indian Shiva in iconographies called Ardhanarishvara is seen as godgoddess, having united with Shakti, the feminine creative power. African myths spawn with half-male and half-female representations as in the case of Mawu-Lisa, or the thunder god Hevioso. These figures represent both the feminine and masculine energies, as well as the wholeness and totality of the universe. 
The Chthonic Realm of Our Psyche

of the whole experience, because it is rooted "in the passing of a soul into the realm of the undead, as a mortal undergoes seduction, acceptance and the partial death of the physical form - a metaphysical intimacy unobtainable between mortals" (1993: 237-238).

A psychological explanation lies behind Dracula's sexuality. David Punter identifies Dracula with "the endless desire of the unconscious for gratification" (1999: 26). He is un-dead, because desire never dies. His existence can never reach the level of satisfaction, for "his very nature is desire" (Punter 1999: 26). That is why he keeps moving on to different objects. Vampiric sexuality becomes a perpetual recurrence. Dracula takes advantage of his victims while they are in a stupor. The blurring of dream and reality brings about nightmare-formationlike hallucinations. The unconscious works. To identify Dracula with the unconscious postulates "undesirable sexuality," that is something which is against the ethics of the Victorian era. In the famous scene when Dracula forces Mina to drink from his chest, Mina is in a stupor, but the intrusion of Van Helsing and Dr Seward awakens her. From this point on, Mina latches on to what is happening to her. As I have implied, Dracula represents the unconscious, the repressed sexual fantasies of Mina, but these fantasies do not necessarily mean all perversions of the vampiric nature. It is as if Mina awakens to her sexuality. Lucy surrenders to her desires, but it goes against Mina's conscience to do so. Mina remains the representation of the "conventional" passive Victorian woman.

According to the Jungian psychology, ethical problems cannot only be brought up by the shadow, but also by the anima and the animus. The animus is the female personification of the unconscious in men, and the anima is the male personification in case of women. Like the shadow, they can have good and bad aspects. They appear in the figure of the opposite sex in dreams. Dracula, the anatomically male represents the animus of Lucy and Mina. If a woman fails to be aware of her negative animus, she can easily be possessed by it;

but if she realizes who and what her animus is and what he does to her, and if she faces these realities instead of allowing herself to be possessed, her animus can turn into an invaluable inner 
MUSKOVITS

companion who endows her with the masculine qualities of initiative, courage, objectivity, and spiritual wisdom.

(Franz 1978: 206)

Lucy becomes possessed by her animus, while Mina is able to turn consciously to hers. After the violent blood drinking scene, when Van Helsing and Dr Seward "awaken" Mina, the girl becomes aware of the negative side of her animus. The masculine qualities of her character are highly praised by Van Helsing later on. Mina avoids animus projection and she can withdraw it by integrating it into her personality. Mina's adventure with Dracula is a process to her individuation.

The three vampiresses and the vampire Lucy are in contrast the anima of the male characters. As Marie-Louise von Franz puts it, "the most frequent manifestations of the anima take the form of erotic fantasy" (1978: 191). This can be observed in the most erotically described scene of the novel, which is the first encounter of Jonathan with the fair vampiress:

The fair girl went on her knees and bent over me, fairly gloating. There was a deliberate voluptuousness which was both thrilling and repulsive, and as she arched her neck she actually licked her lips like an animal, till I could see in the moonlight the moisture shining on the scarlet lips and on the red tongue as it lapped the white sharp teeth. Lower and lower went her head as the lips went below the range of my mouth and chin and seemed about to fasten on my throat. Then she paused, and I could hear the churning sound of her tongue as it licked her teeth and lips, and could feel the hot breath on my neck. Then the skin of my throat began to tingle as one's flesh does when the hand that is to tickle it approaches nearer - nearer. I could feel the soft, shivering touch of the lips on the supersensitive skin of my throat, and the hard dents of two sharp teeth, just touching and pausing there. I closed my eyes in a languorous ecstasy and waited - waited with beating heart.

(Stoker 1994: 52) 
The Chthonic Realm of Our Psyche

Jonathan projects his repressed sexual urges onto the vampire ladies, and the dreamlike quality is accentuated. The figurative language of dreams expresses inner anxieties, and dealing with the darker aspects of the personality, nightmares and dreams have become common devices of Gothic fiction. Dreams mean distance and closeness at the same time. Events occurring in dreams are distant in a sense that they are beyond the borders of reality, but on the other hand they are indicative of the person's inner world and relation to the world. While seemingly new things are shown, the events and figures always represent something familiar. This uncanny effect is accentuated when Jonathan meets the three vampiresses in Dracula's castle, as the following excerpt demonstrates:

I suppose I must have fallen asleep; I hope so, but I fear, for all that followed was startlingly real - so real that now, sitting here in the broad, full sunlight of the morning, I cannot in the least believe that it was all sleep.

I was not alone. The room was the same, unchanged in any way since I came into it; I could see along the floor, in the brilliant moonlight, my own footsteps marked where I had disturbed the long accumulation of dust. In the moonlight opposite me were three young women, ladies by their dress and manner. I thought at the time that I must be dreaming when I saw them, for, though the moonlight was behind them, they threw no shadow on the floor. They came close to me and looked at me for some time and then whispered together. Two were dark, and had high aquiline noses, like the Count's, and great dark, piercing eyes, that seemed to be almost red when contrasted with the pale yellow moon. The other was fair, as fair as can be, with great, wavy masses of golden hair and eyes like pale sapphires. I seemed somehow to know her face, and to know it in connection with some dreamy fear, but I could not recollect at the moment how or where.

(Ib. 50-51)

Jung accentuated the importance of symbols and inner events, a certain kind of introspection. In contrast with Freud, whose theories based on sexual interpretations, Jung's libido concept was seen as 
MUSKOVITS

pure life force in which sexuality is just one way of expressions. "The libido is God and Devil" (1916: 120) reveals Jung the morally divided dual nature of libido. The vampire sucks blood, that is, the energy from conscious life. The consequence of this power and energy loss is that unconscious contents take control over the individual's life. Gothic novels explore the subconscious mind therefore they are almost never devoid of dream and/or nightmare scenes. Vampires are active when it is dark. Deprived of quietus, a ray of light postulates the vampire's instantaneous annihilation, the end of his lugubrious state of existence.

In all cultures the light and dark contrast is of peculiar interest. Light is associated with life, whereas dark is linked to death and the underworld. The vampire goes out hunting from sunset to sunrise and sleeps during the day. People often had anxiety that the sun might fail to rise and the life-giving light never reaches them. Vampires are anti-solar creatures, and their association with darkness links them with the underworld but also with nocturnal activities, such as dreams and nightmares. Dracula rises from his coffin to visit his victim who is comatose. His uprising symbolizes those anxieties, fears, frustration and aggression that are buried within us. If repressed feelings are not overcome, they will surface in due course and begin to disturb us. Vampires are photophobic and in the blaze of day they vanish; that is when they are converted into the conscious, they cease to exist, they stop their perturbing activities. The Dracula story is instructive in this sense, indicating that difficulties should not be avoided, but confronted. Northrop Frye further associates the cycle of waking and dreaming with the cycle of light and darkness, which can apply to Dracula. The hero being a sufferer of frustrations is really in the power of darkness in daylight, explains Frye his antithesis; and the libido, the conquering heroic self awakes in the darkness (Frye 1972: 431).

\section{The subhuman side}

The heroes of the novel face a creature that has "the strength in his hand of twenty men" (244). In its manifestation, Dracula is superhuman, immortal and has power over the minds of humans. He 
The Chthonic Realm of Our Psyche

can hypnotize his victim and this way he can control her. However, pointing out the godlike nature of Dracula is vague in itself. For unfolding a more precise explanation of his nature, I turn to the Jungian archetypes. According to the Jungian view, Dracula can be classified into the so-called trickster archetype, that is:

[h]e is a forerunner of the saviour, and, like him, God, man and animal at once. He is both subhuman and superhuman, a bestial and divine being, whose chief and most alarming characteristic is his unconsciousness. Because of it he is deserted by his (evidently human) companions, which seems to indicate that he has fallen below their level of consciousness. He is so unconscious of himself that his body is not a unity, and his two hands fight each other. He takes his anus off and entrusts it with a special task. Even his sex is optional despite its phallic qualities: he can turn himself into a woman and bear children.

(Jung 1988: 143)

Dracula is in the netherworld and the upper world at the same time, but still anthropomorphic. In folklore, supernatural creatures were thought to come back to haunt people first in the form of demonic spirits, but later they were able to take up physical forms and trespass the world of the living. In medieval mentality there was less distinction between physical and mental as well as religious and nonreligious spheres, no wonder that so many superstitions occurred at the time. Enough to think of witchcraft trials where hundreds of innocent people fell victims to unreasoning frame-ups. The different counts, including denial of the Christian faith and sexual relations with the devil demonstrate well the crossing of the metaphysical realm, that is, the blurring of the two categories mentioned above.

Another characteristic of the trickster is his shape-shifting ability into an animal form (ib. 136). From German mythology, the trickster Loki often changes into an insect or a fly in order to amuse himself by watching the consequences of the mischief he caused. Zeus, the Greek demiurge is known about his frequent shape-shifting when he wanted to carry out his sexual adventures as in the form of a swan when mating with Leda, or in the form of a bull when enticing Europa. 
MUSKOVITS

Vampires also have animal alter-egoes, they can appear in the form of bats or wolves. The earliest association between bats and vampires was drawn by Spanish conquistadors who faced bats which sucked the blood of their cattle and horses in tropical Southern and Central Mexico. This bloodsucking species, the Desmodus rotundus reminded them of the European folkloric vampires, being night fliers and drinking blood, so they called them vampire bats after the European vampire tradition. Although these bats prefer the sanguine flood of warm-blooded animals and birds, they rarely also attack human beings. Dracula can take the shape of a bat, which, psychologically speaking, clearly indicates his subhuman nature. Animals symbolize man's primitive and instinctual side. The animalistic nature of the count indicates that instincts have extracted from the conscious sphere, thus in need of integration.

In addition, Dracula is said to be able to materialize into fog. Fog corresponds to obscurity, when clear view is not available. The inability to see suggests the idea of losing control over one's senses. Gloomy atmosphere surrounds the potential victim of the vampire who is active at night under the cover of darkness. In Stoker's novel Dracula's "blackness" is stressed; he is said to get dressed in black and wear a black hat, and his horses are also depicted as black. This dimness of the count - just like of all the chthonian "children of the night" - is a sign of evil nature. Paradoxical again, his outward appearance suggests the opposite.

\section{The illness of desire}

When vampires are noticed by people, they are described as extremely pale. The vampire spends his daytime in coffin, which explains his unnatural whiteness. Pallor can be associated with several illnesses, which exhibit similar symptoms to vampirism. Pellagra and porphyria, ${ }^{3}$ where photosensitivity is a key sign, are usually

3 Pellagra has three main symptoms: diarrhoea, dermatitis and finally dementia. Those suffering from pellagra are quite aggressive and are without any appetite, so they grow thin quickly. They produce symptoms which are similar to some characteristics of the vampires, because like the 
The Chthonic Realm of Our Psyche

associated with vampirism. In addition, tuberculosis patients have vampiric symptoms such as fatigue, decrepitude, poor appetite, and consequently, loss of weight. A person can acquire bacteria from people living close to them, or can be infected after having got in contact with corpses. This picture fits the vampire myth where the dead (usually family members as it is mentioned in most folklore tales) return, and due to their visits the living person also wastes away. It is similar to a chain reaction, the living become dead, and the dead come alive. Metaphorically speaking it reflects the cycle of life, its natural stages of passing away and birth.

Later tuberculosis was romanticized throughout the nineteenth and early twentieth century and was seen as "a disease apt to strike the hypersensitive, the talented, [and] the passionate" (Sontag 1989: 12). It is definitely not an accidental analogue how the Byronic, aristocratic vampire came to the fore, and the pallor of this (dark) romantic hero correlated with the achromasia of the folkloric bloodsucker. Diseases affect everyday life, and thus have some social aspects. René Dubos explored the social history of tuberculosis in his remarkable book The White Plague: Tuberculosis, Man, and Society, commenting that

[w]hereas the influence of bubonic plague is obvious in Boccaccio's tales, and in the dissolution of morals at certain periods of the Reinassance, the part played by tuberculosis in more recent history is less distinct even though it was profound and lasting. The disease distorted the norms of life and behaviour for several generations by killing young adults or ruining their physical and mental health.

vampires, the pellagric patients are sensitive to sunlight and cannot sleep at night. The other illness, porphyria appears more rarely. It features photosensitivity and in case of not avoiding sunlight, the skin blisters. Patients suffering from porphyria can be cured by blood transfusion. 
MUSKOVITS

In the case of women, whiteness had become a desirable attribute, indicative of these ladies' spiritual, moral and physical purity. This vestal innocence of women was very important at the time when economic and industrial developments were taking place at a great pace, and men were involved in business. Wives were expected to defend the males' soul from damage in the world of commerce, and become keepers of their husbands' soul.

Art reflects social changes, and the anaemic depiction of women became a kind of cult among early Victorian painters. Bram Dijkstra argues that apart from the reflection of the desired feminine moral consciousness, there is also a subtle hint at "social status and economic privilege" (Dijkstra 1986: 28) connecting success with consumptive looks. However, this near-death condition suggested sacrifice on the part of women, and the dutiful submission and the entrapment of domestic life became suffocating for some. "The cult of the woman as corpse" (ib. 46) was beginning to take a different turn in the late nineteenth century: instead of death, women rebelled against this condition and began to "rise from their symbolic coffin". Art had become affluent in beastly females, and the vampire, aptly fitting as visual equivalent of this symbolic uprising, became a popular topic on canvas.

The pale seducer - an obvious paradox since colourful outward features should reflect passion, and the vampire's apparent apathy under the white mask conceals passionate sentiments of all sorts represents the dangerous aspects of the underlying threat to the purity of the soul. Dominated by Christian ideology, these perilous women became stigmatized by the original sin of the fallen woman, temptation. In vampire topos, women who lack moral stability are prone to yielding to the alluring machinations of the vampire, the personification of Evil. When it comes to male characters, they are also tempted by these female figures and it depends on their moral consciousness whether they succumb or not. The result of the vampiric "loving" is death (of the soul) and - while people can die of love - death can not only be the end but also the efficient cause. 
The Chthonic Realm of Our Psyche

\section{Death and rebirth}

The mors in actu motif appears in medical science, in art, and as myth or superstition in folklore. In ancient Greece, moderation was the keyword when it came to men's sexuality (Foucault 1992: 83); guilt was not attached to the practices otherwise. Excess was seen as something that should be controlled by the individual, thus virtue lay in man's ability of self-mastery. The emergence of Christianity ${ }^{4}$ altered the attitude towards sexual issues; it is different from the Ancient Times, especially from the classical Greek period, where more freedom was attached to carnal pleasures. It is striking that negative judgements and attitudes towards nakedness and the body became emphasized when religious sentiment was prevalent in the given periods, basically in the Middle Ages and in the High Victorian era. The moral problematization of sexuality came into foreground at these times. Sexual life was seen as something hideous that should no way be the source of pleasure. Strange it may seem, immoderate sexual intercourse served as an explanation for mors in actu both according to the Antique and Christian views. The reason lies in the fact that in medieval times the inheritance of the antique medical view was very dominant, and the other reason is the strong influence of the Arabian medical science (Horányi-Magyar 1998: 66). Despite the fact that love-making was considered to be neutral from health's point of view, Christian worldview has brought a social anathema on it.

When plague, the pandemic disease called The Black Death swept over the world in the fourteenth century and killed almost half of the population in Europe, people were strongly reminded of the brevity of their earthly existence. Death had become a daily experience, people grew more conscious about the fact that death can come at any minute for anybody regardless of gender, rank, age, or religion. This intensified sense of human frailty manifested itself in iconography known as Dance of Death, or Danse Macabre in French

\footnotetext{
${ }^{4}$ Foucault points out that there is no use of talking about continuity between pagan and Christian sexual morality, because principles are endowed with different values (1992: 21).
} 
MUSKOVITS

and Totentanz in German. In Totentanz pictures death is personified in the form of skeletons who accompany various people to their grave, indicating that death is inevitable for all humans. During this medieval allegory of death, lovers could be victims while walking or caught even during coitus when skeletons brought both or one of them to their way into the other world (Horányi-Magyar 1998: 71). To talk about mors in actu in case of Dracula and his victims is a bit complicated. Vampires cause slow death, their victims die of atrophy. Dracula comes back several times to the sufferers, thus the mors in actu motif is preceded by a long "courtship" before his victims die of anaemia. Furthermore, victims in a way die but soon they transform into an equally evil creature such as their masters, they become undead.

Blood is what guarantees the survival of the species, the keeping up of the living dead mode of being. Representing vitality, blood also makes Dracula young - but this youth operates only on the outside. The vampire is an ancient creature who is supposed to live for hundreds of years without changing in appearance. Dracula's youth originates from an afterlife condition. The vampiric non-existence in the ethical sphere can be two-fold. First of all, if staked, vampires can be liberated from the shackles of Hell, as will be observed in case of Lucy, who transforms back to her virtuous image. Secondly, moral uncertainty may follow. The arch vampire Dracula simply just ceases to exist, crumbles into dust, and nothing is known about his ultimate faith.

The instructive moral lessons of the traditional Christian religion, according to which, if one is good, he or she will go to Heaven, and if one is bad, then he or she will be punished in Hell. The belief in salvation and damnation in Stoker's time had been challenged by Darwin and science. In Dracula, Professor Van Helsing represents the man of science, although he believes in vampires, therefore his character is a proper manifestation of the Victorian doubts and uncertainty occurring between the rational and the irrational. The dichotomy between morality and immorality still corresponds to Heaven and Hell in the vampire narrative. The vampire is the personification of immoral qualities. Those infected by the bloodsucker can expect the suffering of the netherworld, and those 
The Chthonic Realm of Our Psyche

virtuous people who put up resistance have a good chance to go to Heaven. In this sense the vampire is a morality marker.

\section{Conclusion}

The vampire myth is pervaded by death and sex taboos. The character of the vampire is a storehouse for binary oppositions such as living/dead, creator/destroyer, male/female, superhuman/subhuman, ancient/young, which are common features of mythic deities. This ambiguity correlates with underlying psychological explanations regarding Dracula. The resurrection of the vampire entails positive and negative aspects. Creating such a deity reflects people's wishes and fantasies, but in a dislocated realm of morality. Dracula represents the darker side of the psyche, and despite its seemingly evil, confrontation with "him" is of positive nature, thus with a moral lesson.

\section{References}

Bunson, M. 1993. Vampire the Encyclopcedia. London: Thames and Hudson Ltd..

Dijkstra, B. 1986. Idols of Perversity. Fantasies of Feminine Evil in Fin-deSiécle Culture. New York, Oxford: Oxford University Press.

Dubos, R. 1987. The White Plague: Tuberculosis, Man, and Society. New Jersey: Rutgers University Press.

Foucault, M. 1992. The Use of Pleasure. The History of Sexuality Volume 2. London: Penguin Books.

Franz, M-L. von 1978. The Process of Individuation. - Man and his Symbols. Ed. Carl G. Jung. London: Picador.

Freud, S. 2001. The Uncanny. - The Norton Anthology of Theory and Criticism. ed. Vincent B. Leitch. New York, London: W. W. Norton \& Company, Inc..

- 1918. Totem and Taboo. Resemblances Between the Psychic Lives of Savages and Neurotics. New York: Moffat, Yard and Company.

Frye, N. 1972. The Archetypes of Literature. - 20th Century Literary Criticism: A Reader, ed. David Londge, London: Longman, 422-433.

Holy Bible: New Living Translation. 1997. Wheaton: Tyndale House Publishers. 
MUSKOVITS

Horányi Ildikó, Magyar László András. Halálos szerelem. Mors in actu. Világosság, 1998/7, 64-80.

Jung, C. G. 1988. Four Archetypes: Mother, Rebirth, Spirit, Trickster. London; New York: Ark.

- 1916. Psychology of the Unconscious. A Study of the Transformations and Symbolisms of the Libido. New York: Moffat, Yard and Company.

Punter, D. 1999. Dracula and Taboo. - Dracula: Bram Stoker. Ed. Glennis Byron. Basingstoke; London: Macmillan \& Co.; New York: Saint Martin's Press Inc., 22-29.

Sontag, S. 1989. AIDS and its Metaphors. Penguin Books.

Stoker, B. 1994. Dracula. London: Penguin Books Ltd. 